\title{
Human values: A cognitive perspective
}

\author{
Daniel Sznycer
}
Oklahoma Center for Evolutionary Analysis, Department of Psychology, Oklahoma State University, Stillwater, OK 74078-3064.

Corresponding Author: Daniel Sznycer

E-mail: daniel.sznycer@okstate.edu

\begin{abstract}
Things afford positive, neutral, or negative long-run effects on the replicative probability of the focal individual's genes. At the most general level, values are internal estimates of those effects. Value information steers physiology and behavior in the right direction: approach apple, avoid lion. Thus, value computation is of paramount biological importance. Task analysis suggests there are many prerequisites for valuing things aptly. Here, I focus on two: the need to compute value accurately, and the need to properly feed and integrate value information into the various systems that use value information (e.g., emotion). For example, the subjective food value imputed to an apple needs to reflect the nutrient content of the apple (accuracy); the intensity of gratitude aroused if someone gave you an apple needs to reflect the food value imputed to the apple (integration). Here, I evaluate these hypotheses with two preregistered studies. Consistent with the integration hypothesis, there are close correspondences between $(i)$ the food values that participants impute to each of 40 food items (Study 1; goods) and (ii) the social values and the social emotions (including: gratitude, anger, shame, and pride) that result when those food items occur as constituents of broader social events. Similar correspondences are observed when participants evaluate each of 28 diseases and injuries (Study 2; bads). Consistent with the accuracy hypothesis, exploratory analyses indicate that the food values, the social values, and the social emotions elicited by the food items all track the nutrient content of those food items. Valuation is inherently a computational process. For this reason, a cognitive perspective is distinctively suited to spur progress in our understanding of human values.
\end{abstract}




\section{Introduction}

Human values are a window into human nature. Know what things people value and disvalue, and you will know what things people need in order to stay alive; what forms of social organization people favor; what personal characteristics people deem virtuous; what allocations of resources people deem fair; what stories pique people's interest; what goods and services people truck, barter, and exchange; what predators, pests, and diseases rack societies; and so on. Perhaps because of this, much effort has been devoted to understanding human values.

Considerable research on human values is descriptive and typological. This research tradition has given us rich accounts of values that are held universally, or across broad cultural areas: security, benevolence (Schwartz \& Bilsky, 1987), true friendship, forgiveness (Rokeach, 1973), survival, self-expression (Inglehart, 2007), individualism, collectivism (Hofstede, 2001; Triandis, 1993), beauty, honesty (Maslow, 2013), prudence, temperance, and justice (Plato, 1943).

In addition to these abstractions, however, people also value a vast number of specific things: water, rice, meat, potatoes, khat, obsidian, shelter, harpoons, baskets, fire, fireextinguishers, reciprocating saws, double-entry bookkeeping, the Pilgrimage of Compostela, analgesics, spectroscopy, shark fins, money, etiquette, sleeping, whispering when the baby is getting asleep, normal blood oxygen levels, savanna-like landscapes, direct routes, explanations, gossiping, offspring, parents, siblings, friends - the list goes on more or less ad infinitum. A theory of human values needs to account for all of these values - those held by all, those held by the many, and those held by the few.

How do humans value the things that they value? And what is a value, that the brain would have evolved to compute it? Here, I sketch a cognitive theory of human values. I also offer data relevant to two hypothesized pre-requisites for human value computation. An extended theory will be offered elsewhere.

\section{What is a value?}

Things, organisms, events, and states of affair afford positive, neutral, or negative long-run effects on the replicative probability of the focal individual's genes. At the most general level, values are internal estimates of those effects. Values are useful: They can be accessed by regulatory mechanisms to steer decision, physiology, and behavior in the right direction (Jackendoff, 2006; Tooby et al., 2008; Rangel, 2009). You can get nutrients from apples, and because this is echoed in your valuation of apples, you approach apples. Lions can get nutrients from you, and because this is echoed in your valuation of lions, you avoid lions.

Knowing the value of things allows economy in decision-making and behavior. For example, if you know the food value of a food item, you can internally match this value to your inclination to search for, collect, and process that food item so that the cost of acquiring does not exceed the benefit of consuming. You might be willing to trek two miles to a target location and two miles back home, and spend $400 \mathrm{kcal}$, if you know in that location there is a honeycomb full of honey, worth $1200 \mathrm{kcal}$. But you would not trek four miles if you know all you can get is one apple, worth $100 \mathrm{kcal}$ (see Charnov, 1976).

Valuing things comes naturally to us. But valuing things would a forbidding task if we lacked the information-processing machinery that enables value computation and that needs to be understood.

\section{Prerequisites for valuing things aptly}


Here, I focus on natural value computation: the set of evaluative processes that occur spontaneously and without the need of special instruction and that can be discerned universally or near-universally across the members of the human species (or within a sex or life-stage) by virtue of reliably-developing information-processing machinery.

Many information-processing prerequisites are necessary to value adaptively, in a way that would promote the survival and reproduction of the valuer. Here, I focus on two of them: The need to properly integrate value information into the various systems that use value information in their computations, and the need to compute value accurately.

\subsection{Integration}

There is a vast number of vastly different things that afford value, positive or negative, to humans. But different things afford value through different causes and effects. You get nutrients from apples, help from friends, and tissue damage from injuries. The cues the cognitive architecture exploits to compute value vary correspondingly. You can tell the value of an apple from its sweetness, the value of a friend from how much she will give up in order to help you, and the (negative) value of an injury from your pain and incapacitation. Further, the systems that are regulated on the basis of value information are many and varied. The apple is ingested and its sugar is turned to ATP to fuel cellular processes. The friend is thanked and helped when she is in need. Injury triggers inflammation and lassitude (Schrock et al., 2019). There is a quantity of apples that affords your genes the same incremental probability of replication as your friend does. But the procedures that estimate the value of the apples and of your friend (on the input side) and the best-bet responses vis-à-vis the apples and your friend (on the output side) are different. These considerations suggest that valuation procedures are content-specific and analytic. Content-specific, because each type of thing needs to be appraised in its own proper way. And analytic, because each thing in a scene needs to be appraised on its own ${ }^{1}$.

Value sometimes needs to be estimated at a relatively high level of analysis, however, and so integrative valuation procedures are expected as well. Things can afford multiple different types and magnitudes of values at various levels of analysis, the way a sentence and its various lower-level constituents can be evaluated in terms of their syntax, semantics, and phonology. Integrative procedures allow value computation up one level.

Integration is necessary to value even simple things. Things with two or more adaptively relevant attributes often demand integration because action is unitary and irrevocable - action often cannot be performed to best-fit every attribute. Barring the most uniform, things amalgamate different components and qualities, and thus can afford multiple values. For example, one cabbage contains nutrients of various types: water, sugar, protein, fiber, vitamin C, and others (U.S. Department of Agriculture, Agricultural Research Service, 2019). One cabbage also contains 49 natural pesticides, some of which are carcinogenic (Ames et al., 1990). Each of these components has its own characteristic effect, positive or negative, on the valuer's prospects. Therefore, the value of each component is worth computing, in principle. In addition, however, a single cabbage-wide food value needs to be computed if one is to, for example, decide whether or not it pays to search for the cabbage to eat it.

${ }^{1}$ If you walk into a room and see one apple $(+1)$ and one poisonous insect $(-1)$, it would be a mistake to impute a single scene-wide value of 0 and act the same way as if there was neither apple nor insect. The scene-wide value (in retrospect) is positive, if you can eat the apple and avoid the insect. 
Similarly, integration is likely necessary to compute the social value of a social partner. For instance, a candidate mate embodies multiple qualities: a given level of kindness, a given reproductive value, a given level of social status, a given level of aggressiveness, etc. Recent research suggests that people integrate a candidate mate's various qualities-people impute higher overall attractiveness as the Euclidean distance between the quality amalgam of a candidate mate and the quality amalgam of one's ideal mate decreases (Conroy-Beam \& Buss, 2017).

Integration is necessary also for valuing in prospect - much of the valuation performed in the real world. The value of an apple is an uncertain estimate, especially if you haven't yet eaten it and used up all its nutrients. The apple might rot, be eaten by someone else, etc. To value in prospect, it is necessary to integrate so that value is discounted by the estimated probability or delay (Green et al., 2014). Integration is necessary also for choice behavior. In this way (for example), the units already consumed or the acquisition cost are appropriately factored into the net value imputed to the next unit of a thing (Basten et al., 2010; Croxson et al., 2009). You might value apples better than oranges, everything else equal. But you might choose to forage for oranges over apples if, for example, you ate apples recently, or the orange grove is nearer you than the apple orchard is (Guzmán et al., under review).

Integration is necessary also for valuing bundles (Park et al., 2011). You might feel that having two apples is better than having one apple; that having one apple and one almond is better than having one apple; that having one apple and one fractured hip is worse than having one apple, etc. Valuing bundles sometimes requires the ability to compare apples and oranges - to render different internal currencies of value into a common currency. Indeed, neuroscientific evidence suggests there is a common neural currency of value (Levy \& Glimcher, 2011, 2012; Lin et al., 2012; McNamee et al., 2013). Valuing bundles also requires the abilities to estimate number and physical quantities and to engage in arithmetic reasoning-operations which nonhuman animals and humans without mathematical training are capable of (Barth et al., 2006; Dehaene, 2009; Gallistel, 1990; Gallistel \& Gelman, 1992; Xu, 2003).

Integration is necessary also for evaluating complex scenes. Things that afford value sometimes occur embedded in broader scenes, events, or relations that also afford value, including value of a different type. If your neighbor gives you an apple, there is food value in the apple and there is social value in having your apple-giving neighbor around (Tooby \& Cosmides, 1996; Aktipis et al., 2018). To know the latter, your brain must estimate the incremental social value of your neighbor (to you) given the fact that she gave you an apple. Her incremental social value is in part a function of the food value of the apple that she gave you (imagine she gives you a whole roast pig instead). Her incremental social value is also a function of variables relevant to social-evaluative psychology (e.g., how costly was it for her to give you the apple? (Tesser et al., 1968; Lim, 2012). One prerequisite, in this case, is that multiple chunks of value information be acquired and processed by the right machinery and bound to the right variables. For example, the food value of the apple dictates your motivation to eat the apple (Hinton et al., 2004) and your motivation to help your neighbor subsequently (see Forster et al., 2017). In contrast, the cost your neighbor incurred by giving you the apple determines your motivation to help your neighbor (Lim, 2012) but (likely) not your motivation to eat the apple. This binding problem might be solved in part through enzymatic computation (Barrett, 2005). If, for example, information about the cost incurred by a donor is an argument of social value (e.g., an argument of the incremental social value you impute to a donor due to her giving you a gift) but not of food value, then donor-cost information is appropriately restricted in its scope of application 
simply because it can be integrated with social value information but not with food value information (see Tooby \& Cosmides, 2000).

Value integration appears to be subserved by a host of design features and procedures, and to serve various functions. But a common feature of value integration is that lower-level value information is faithfully transmitted across systems and appropriately echoed in the relevant higher-level outputs.

\subsection{Accuracy}

Integration is necessary for valuing adaptively. But it is not sufficient. Value also needs to be computed accurately.

Valuing things accurately is challenging. The net effect of a thing on the replication rate of the valuer's genes - the biologically relevant magnitude - is not known and cannot be known to a valuer, because valuers have imperfect information and limited computing power (Simon, 1955). In addition, the effects of a thing on the valuer often are not revealed until after the valuer has imputed value. These challenges are highly consequential, because the effects of a thing (e.g., an ingested food, an acquired habit or technique, an act of sex with an individual) on the valuer's genes continue to accrue long after the valuer is dead (Cosmides \& Tooby, 1994). Valuing accurately is not entirely hopeless, however, because the here and now is saturated with perceivable cues that are causally linked to fitness effects counting from the ancestral past.

To value accurately, the value imputed to a thing must correspond to one or more attributes of the thing that would have been, and might still be, causally linked to fitness effects. For example, the food value imputed to a food item found in the valuer's local ecology must correspond to the nutrient content of that food item. If food item $a$ has more nutrients than food item $b$ does, this difference needs to be echoed in value computation so that more food value is imputed to the former than to the latter.

Accuracy in value computation is expected for those things that exerted selective effects of sufficient size or with sufficient regularity that the benefits of valuing accurately would have exceeded the costs of valuing accurately: animal and plant species (see New et al., 2007), social partners, coalitions, social contracts (Cosmides \& Tooby, 1992), situations, plans, habitats, and bodily injuries; but not, for example, Picasso paintings or electricity futures - although the latter can be acquired with instruction (see Hofmann et al., 2010). Accuracy in value computation is expected to the extent there are cues of value that can be perceived and exploited to estimate value. Accuracy will suffer if perceivable cues are not available (e.g., in carbon monoxide), or if the cues are partial or occluded (e.g., an apple rotting from the inside) or altered deliberately (e.g., a face with cosmetic surgery). Accuracy will suffer also if an evolved nexus between cue, evaluative psychology, and fitness effect becomes decoupled. For example, the evolutionarily recent appearance of the rule of law and police forces may have outdated the subjective value of lethal aggression as a means to solve conflicts in one's favor.

\section{Value information serves as input to multiple systems}

Value information serves as input to multiple systems, including motivation systems, emotion systems, and value estimators.

Value information serves as input to motivation systems. Valued things are approached. Disvalued things are avoided (Elliot, 2006; Lewin, 1935) — or approached if they can be removed or eliminated cost-effectively (see Sell \& Lopez, 2020; Oprea et al., 2011). Things of high value, positive or negative, are more likely to lead to appetitive and consummatory behavior, or to 
avoidant behavior, and to higher intensity and persistence of those behaviors (Roesch \& Olson, 2004; Shadmehr \& Ahmed, 2020; Stellar \& Stellar, 1985). A bit of value information can be fed to multiple systems and have different, even opposite effects on the intensity of the resulting motivation, depending on which system uses this information. For example, the kinship value (or index) an individual imputes to an opposite-sex target - the degree to which the target is perceived as being genetically related to the focal individual - is positively associated with the individual's motivation to help the target, and negatively associated with the individual's motivation to have sex with the target (Lieberman et al., 2007; Sznycer, De Smet, et al., 2016; Tanskanen et al., 2021).

Value information also serves as input to emotion systems. Value plays a central role in anger, gratitude, shame, guilt, pride, jealousy, and other social emotions (Cosmides \& Tooby, 2000; Tooby \& Cosmides, 2008; Tooby et al., 2008; Sznycer \& Lukaszewski, 2019). The social emotions appear to be adaptations that coordinate the operation of various lower-level adaptations in the service of recalibrating the social valuations held by self and others (Tooby \& Cosmides, 1990b, 2008; Al-Shawaf et al., 2016; Delton \& Robertson, 2016; Sznycer, Cosmides, et al., 2017; Sznycer et al., 2021). For example, anger is mobilized when there are indications that another individual attaches insufficient value to one's welfare-less than what one can costeffectively enforce from them (Sell, 2005). Once mobilized, anger entrains various lower-level adaptations with the aim of incentivizing the offender to value one's welfare more highly (Sell, 2005, 2011; Sell \& Sznycer, In press; Sznycer et al., under review). The anger system can effect a host of internal changes, including: downregulation of the motivation to deliver benefits to the offender (Sell, 2005; Lim, 2012; Sznycer et al., under review); upregulation of the motivation to impose costs on the offender through direct or indirect aggression (Daly \& Wilson, 1988; Felson, 1982; Sell et al., 2009; Wyckoff, 2016); upregulation of heart rate, blood pressure, and respiration rate in preparation for escalation (Siegel et al., 2018); and bargaining-related communications directed at the offender, both verbal (Sell, Sznycer, et al., 2017) and non-verbal (Galati et al., 2003; Sell et al., 2014).

Value is relevant to other social emotions as well. For example, gratitude is elicited by indications that another individual affords positive social value to the self (e.g., because the other has helped the self). Once elicited, gratitude upregulates the value attached to the other's welfare, and aims to cement a cooperative relationship with the other (Algoe et al., 2008; Forster et al., 2017; Lim, 2012; Smith et al., 2017a; Tesser et al., 1968). Shame is elicited by indications of probable or actual devaluation from others due to the spread of negative about the self. Once elicited, shame mobilizes various responses geared to limiting the likelihood and costs of being devalued (Gilbert, 1997, 1998; Landers et al., In press; Durkee et al., 2019; Sznycer, Tooby, et al., 2016; Sznycer, 2019; Sznycer \& Cohen, 2021a; Cohen et al., 2020). Pride functions to capitalize on opportunities to become more highly valued by others. Once elicited, pride directs the individual to take actions or to cultivate traits that are valued (or feared) by others, to advertise those actions and traits, and to demand enhanced valuation from others (Fessler, 1999; Sznycer, Al-Shawaf, et al., 2017; Sznycer, Xygalatas, Alami, et al., 2018; Sznycer \& Cohen, 2021b; Tracy et al., 2010; Weisfeld \& Dillon, 2012)

Value information also serves as input to mechanisms that compute value. Value can be fed to procedures that output values of the same type. For example, the food value imputed to a bundle of apples is a function of the food value imputed to the apples in the bundle. Value can also be fed to procedures that output values of a different type. For example, the status-value imputed to a target individual is a function of the quantity and quality of the goods that the target 
produces (Von Rueden, 2014), shares with others (Durkee et al., 2020), consumes (Veblen, 1899), or destroys (Piddocke, 1965).

The various systems that take value information as input (motivation systems, emotion systems, value estimators, and others) have different adaptive functions, perform different computations, and produce different types of outputs. However, these various systems may employ the same type of value information, and a given bit value information may be fed to different types of systems.

For example, the subjective food value imputed to an actual or imagined apple on the basis of perceived or known or imagined cues of the nutrients it contains may elicit various motivations: to search for the apple, to eat the apple, to guard the apple against theft, etc. In addition, the food value imputed to the apple may elicit various emotions: gratitude (e.g., if someone gives you an apple), anger (e.g., if someone steals your apple), etc. Further, the food value imputed to the apple may be rendered into value; for example, social value, such that one attaches positive incremental value to the welfare of those individuals who can produce apples. Critically, however, the motivations, the felt emotions, and the social values that result from the food value imputed to the apple will - if the computations that give rise to them are indeed based on the same food value information-scale in intensity or magnitude with the food value imputed to the apple at the source. For instance, if more food value is imputed to an apple than to a blueberry (on the architecture's assumption that the nutrient content of the apple is higher than that of the blueberry), then everything else being equal, more intense motivation will be elicited to exert effort in order to acquire one apple (vs. one blueberry), more gratitude will be elicited if someone gives you one apple (vs. one blueberry), more social value will be imputed to an individual if she is able to produce one apple (vs. one blueberry), and so on. Note that this projection of proportionalities is functional, because it allows the computational and regulatory processes that depend on value information to avoid the errors of delivering their outputs with either insufficient or excessive intensity. Note also that in this hypothetical scenario the food value information transmitted through these various systems is the same, but this value information acquires different meanings depending on which system accesses it (Tooby et al., 2008).

Similar correspondences are expected when it comes to bads instead of goods. For example, if more (negative) injury value is imputed to a hip fracture than to a wrist sprain (on the architecture's assumption that the hip fracture is more deleterious than the wrist sprain), then everything else being equal, more intense motivation will be elicited to trade goods in order to get a hip fracture (vs. a wrist sprain) cured, more gratitude will be elicited if someone treats and cures your hip fracture (vs. your wrist sprain), more social value will be imputed to an individual if she can cure hip fractures (vs. wrist sprains), and so on.

These integrations of value into motivation, into emotion, and into value are possible because, by hypothesis, value information is transmitted to motivation systems, to emotion systems, and to value estimators, and echoed in the outputs of those systems. These integrations are rational, because the value differentials upstream (e.g., food value of apple $>$ food value of blueberry) are faithfully preserved downstream in the multiple systems that use value information and in the outputs of these systems. These integrations are adaptive, because they enable the cognitive architecture to cost-effectively tailor cognition, physiology, and behavior to the fitness affordances of the things, individuals, events, and states of affairs wherefrom value is computed (e.g., acquire cookie; remove evidence that you took a cookie from the cookie jar; thank and revalue the person who cured your hip fracture). 


\section{Predictions}

Predictions derived from the preceding hypotheses were tested in two preregistered studies. Study 1 (about goods) evaluates participants' responses regarding each of 40 food items. Study 2 (about bads) evaluates participants' responses regarding each of 28 diseases/injuries.

Study 1. First, it is predicted that the social values and the social emotions elicited by each of 40 food items (when the food items occur as part of broader social events) will correlate positively with one another. More specifically, the following variables are predicted to correlate positively with one another: (1) the degree to which participants would view a target individual positively if the target went out to find food and managed to get a given food item (social value); (2) the degree to which participants would feel gratitude at a target individual if the target gave the participant that food item; (3) the degree to which participants would feel anger at a target individual if the target stole that food item from the participant; (4) the degree to which participants would feel shame if they stole that food item from a target individual and the target found out; (5) the degree to which participants would feel pride if they were able to obtain that food item to feed their own child.

Second, the social values and the social emotions elicited by each of the 40 food items are all predicted to correlate positively with the food values imputed to those food items.

Third, there will be between-participant agreement in how each food item is rated relative to the other 39 food items: This will be so for all the measured variables: food value, social value, gratitude, anger, shame, and pride.

In addition, I conduct exploratory analyses relevant to accuracy, to establish whether the ratings of food value, social value, gratitude, anger, shame, and pride elicited on the basis of each of the 40 food items track the nutrient content of those food items.

Study 2. Predictions 1-3 are evaluated also in Study 2, but with respect to each of 28 nonsocial bads: diseases and injuries (12 diseases, 16 injuries).

\section{Study 1. Goods: Food}

\section{Method}

Procedure, stimuli, sample size, exclusion criteria, predictions, and analyses were preregistered before data collection began: https://aspredicted.org/blind.php?x=pk6n96.

\section{Participants and procedure}

Standard power analyses to determine participant sample size could not be conducted because the correlations are computed over the sample of items (fixed in quantity), not over participants. However, pilot data suggested that 25 participants per condition yield adequate power. This number was supplemented to compensate for likely exclusions due to participant inattention. I assumed $15 \%$ of data exclusions due to inattention, and thus set the total number of participants to be recruited to 180: 30 participants per condition.

I collected data with Amazon Mechanical Turk from 177 participants ( 90 females) in the United States. As per the preregistration protocol, participants were excluded from analyses if they failed to pass an attention check. Five participants were excluded from analyses due to inattention. This resulted in an effective sample of 172 participants ( 88 females) (age: $M=40$, $\mathrm{SD}=14)$. 
The stimuli consist of 40 brief questions relevant to 40 food items; one question per food item. The following are some of the food items included in the stimuli: one chicken nugget; one melon; one almond; one handful of cilantro; three eggs, scrambled. Participants were randomly assigned to one of six between-subjects conditions: food value, social value, gratitude, anger, shame, pride. In all six conditions participants gave their responses about the same basic set of 40 food items. The main difference between the conditions was the specific questions that were asked about the food items.

Participants were asked the following questions, for each of the 40 food items. In the food value condition: How much enjoyment they would get if they ate the food item. In the social value condition, how positively they would view a target individual if the target went out to find food for lunch and managed to get the food item. In the gratitude condition: How much gratitude they would feel toward a target individual if the target gave the participant the food item. In the anger condition: How much anger they would feel at a target individual if the target stole the food item from the participant. In the shame condition: How much shame they would feel if they stole the food item from a target individual and then the target found out about that. In the pride condition: How much pride they would feel if they were able to obtain the food item to feed their child at lunchtime.

Participants gave their responses on the following scales. In the food value condition: 0 (no enjoyment at all) to 100 (extreme enjoyment). In the social value condition: 0 (not positively at all) to 100 (extremely positively). In the gratitude condition: 0 (no gratitude at all) to 100 (extreme gratitude). In the anger condition: 0 (no anger at all) to 100 (extreme anger). In the shame condition: 0 (no shame at all) to 100 (extreme shame). In the pride condition: 0 (no pride at all) to 100 (extreme pride).

Each participant completed one of the six sets of 40 questions. The 40 questions were presented in randomized order within conditions. The questions and the food items are described in the Appendix, Tables S1 \& S3.

\section{Results}

The stimuli and the data are available in the OSF repository: https://osf.io/7tdkh/?view_only=c25edd59103c41b48e55334cc63f4b7b. The descriptive statistics are provided in Table S3.

Do participants agree on how they rate the food items? Yes. To measure betweenparticipant agreement in how they rate the 40 food items relative to one another, I computed intra-class correlations (ICC). There was widespread agreement: food value: $\operatorname{ICC}(2,28)=.90$; social value: $\operatorname{ICC}(2,28)=.95$; gratitude: $\operatorname{ICC}(2,30)=.94$; anger: $\operatorname{ICC}(2,28)=.90$; shame: $\operatorname{ICC}$ $(2,29)=.87$; pride: $\operatorname{ICC}(2,29)=.91 ;$ all $P$ s $<<.05$.

Do the food values imputed to the food items correlate positively with the social values and the social emotions elicited by the food items? Yes. The food values imputed to the food items correlated positively with the social values and the social emotions elicited on the basis of the food items. For each of the 40 food items, I calculated the mean ratings (across participants) of each of the six types of ratings: food value, social value, gratitude, anger, shame, and pride. The food values imputed to the food items correlated positively with: the social value attached to targets who are capable of obtaining the food item $\left(r=.84, P=10^{-11}\right)$, the intensity of gratitude directed at targets who give the food item to the participant $\left(r=.83, P=10^{-10}\right)$, the intensity of anger directed at targets who steal the food item from the participant $\left(r=.81, P=10^{-9}\right)$, the intensity of shame felt if the participant stole the food item from a target and the target found out 
$\left(r=.76, P=10^{-8}\right)$, and the intensity of pride felt if the participant were able to obtain the food item to feed their own child $\left(r=.79, P=10^{-9}\right)$ (Figs. 1, panels A-E; Table 1). Further, these associations all held in mixed models predicting ratings of social value (or ratings of social emotions) from ratings of food value across the 40 food items. In these mixed models, the intercept and slope of social value ratings (or emotion ratings) were modeled as fixed effects while the participant-level social value (or emotion) intercept was modeled as a random effect (see Table 2 for model statistics). Thus, the observed associations between social value and social emotions on the one hand and food value on the other hand are unlikely to be driven by participant-level error (Judd et al., 2012).

Recall that the ratings of food value, social value, gratitude, anger, shame, and pride originated from different participants. Consequently, the associations reported above cannot be attributed to participants matching their responses across different types of ratings.

Do the ratings of social value and social emotions correlate positively with one other? Yes. The ratings of social value, gratitude, anger, shame, and pride were positively correlated with one other, with a mean $r=.92(\mathrm{SD}=.03$; minimum $r=.87$; maximum $r=.95$; $\mathrm{N} r$ values $=10)$; $P$ values $=10^{-20}-10^{-12}$.

Do the food values, the social values, and the emotions elicited by the food items track the nutrient content of those food items? Yes. To answer this question, I conducted six sets of exploratory regression analyses, one for each of the following six measured variables: food value, social value, gratitude, anger, shame, and pride. These variables were entered as the dependent variable in each regression. There were four independent variables in each set of regressions: (1) carbohydrate content of the food item, (2) protein content of the food item, (3) lipid content of the food item, and (4) weight of the food item. These four independent variables were entered either singly or all together, for a total of five regression models per dependent variable. Information on the nutrient content of the food items (Table S3) was compiled from the U.S. Department of Agriculture, Agricultural Research Service (2019). The carbohydrate, protein, and lipid contents - the ones used in the regressions - were scaled to the average weight of each food item as it was presented in the stimuli.

When the four independent variables (carbohydrate, protein, lipid, item weight) were entered singly, each variable positively and significantly predicted each of the six dependent variables (food value, social value, gratitude, anger, shame, and pride) (Tables 1, S5-S10). When the four independent variables were entered simultaneously, protein content uniquely and positively predicted 6 of the 6 dependent variables, and carbohydrate content uniquely and positively predicted 5 of the 6 dependent variables (all except shame). In no full model was lipid content or item weight a unique predictor. In the full models, the four independent variables jointly predicted $31-68 \%$ of the variance in participants' ratings (Tables S5-S10). In sum, each of the six sets of participants' ratings relevant to the food items are positively and uniquely associated with the protein content of the food items, with the carbohydrate content of the food items, or with both.

In similar sets of regressions but with sugar content (the subset of carbohydrates with lower molecular weight) instead of carbohydrate content (the set including sugars, starches, and cellulose), protein content is a reliable predictor, but sugar content does not predict any of the six dependent variables, whether singly or in the full models (Tables 1, S11-S16) ${ }^{2}$.

\footnotetext{
2 The original preregistered plan was to conduct the exploratory regressions with energy content instead of carbohydrate content (and instead of sugar content). However, energy content is
} 
Running head: HUMAN VALUES

Are similar results observed when it comes to bads instead of goods? To find out, I conducted Study 2.

inappropriate in multiple regressions since energy content is a function of multiple nutrient types, including carbohydrates, lipids, and proteins. Reflecting this, the multiple regressions with energy content suffer from multicollinearity (VIF higher than the recommended cutoff of 10). Therefore, here I present zero-order correlations, but not regressions, involving energy content (energy content is positively associated with each of the six sets of participants' ratings; Table 1). 
Running head: HUMAN VALUES

\section{Table 1}

Study 1. Correlations between participants' ratings regarding the food items and the nutrient content of those food items.

\begin{tabular}{llllllllllll}
$(1)$ & $(2)$ & $(3)$ & $(4)$ & $(5)$ & $(6)$ & (7) & (8) & (9) & (10) & (11) & (12) \\
\hline
\end{tabular}

(1) Food value

(2) Social value

.84

(3) Gratitude

$.83 \quad .95$

(4) Anger

$\begin{array}{lll}.81 & .93 & .93\end{array}$

(5) Shame

$\begin{array}{llll}.76 & .91 & .93 & .92\end{array}$

(6) Pride

$\begin{array}{lllll}.79 & .94 & .95 & .87 & .89\end{array}$

(7) Energy (kcal)

\begin{tabular}{llllll|}
.56 & .75 & .77 & .74 & .75 & .80
\end{tabular}

(8) Carbohydrate (g)

$\begin{array}{lllllll}.38 & .33 & .45 & .35 & .33 & .45 & .57\end{array}$

(9) Sugar (g)

$\begin{array}{llllllll}.16 & .02 & .15 & .07 & .06 & .13 & .17 & .67\end{array}$

(10) Protein $(\mathrm{g})$

$\begin{array}{lllllllll}.45 & .74 & .69 & .71 & .73 & .70 & .69 & .00 & -.12\end{array}$

(11) Lipid (g)

$.38 \quad .58$

$.33 \quad .38$

$38 \quad .50$

$54 \quad .56$

$.56 \quad .60$

$\begin{array}{lllll}.60 & .85 & .18 & -.16 & .57\end{array}$

Note: Coefficients are Pearson's $r \mathrm{~s}$. $\mathrm{N}$ on which the correlations are based $=$ number of items $=$ 40. Ratings of food value, social value, gratitude, anger, shame, and pride were given by different participants. Non-grey cells: directional predictions; 1-tailed tests. Grey cells: exploratory tests; 2 -tailed tests. Bolded coefficients: $P<$ or $\langle<.05$; non-bolded coefficients: $P>$ or $>.05$. 
Running head: HUMAN VALUES

Table 2

Fixed effects of food value (or disease/injury value) on social value and social emotions, from mixed models

Predictor

Food value imputed to food item

\begin{tabular}{lll}
\multicolumn{3}{c}{ CI $]$} \\
\hline Social value & $.98[.89 ; 1.07]$ & $t(1091)=22.00, p=10^{-88}$ \\
Gratitude & $.94[.85 ; 1.03]$ & $t(1169)=20.55, p=10^{-79}$ \\
Anger & $.68[.59 ; .77]$ & $t(1091)=15.47, p=10^{-48}$ \\
Shame & $.44[.38 ; .51]$ & $t(1130)=12.69, p=10^{-34}$ \\
Pride & $.70[.62 ; .79]$ & $t(1130)=15.65, p=10^{-49}$ \\
& & \\
Social value & $.44[.38 ; .50]$ & $t(728)=14.04, p=10^{-39}$ \\
Gratitude & $.37[.31 ; .43]$ & $t(782)=11.84, p=10^{-29}$ \\
Anger & $.60[.53 ; .67]$ & $t(782)=16.81, p=10^{-53}$ \\
Shame & $.43[.34 ; .51]$ & $t(782)=9.77, p=10^{-20}$ \\
Pride & $.68[.59 ; .76]$ & $t(782)=15.27, p=10^{-45}$ \\
\hline
\end{tabular}

Note: In each mixed model, the intercept and slope of social value ratings and social emotion ratings on food value (or disease/injury value) ratings were modeled as fixed effects (using type III sum of squares), while the participant-level social value or social emotion intercept was modeled as a random effect. 
Running head: HUMAN VALUES

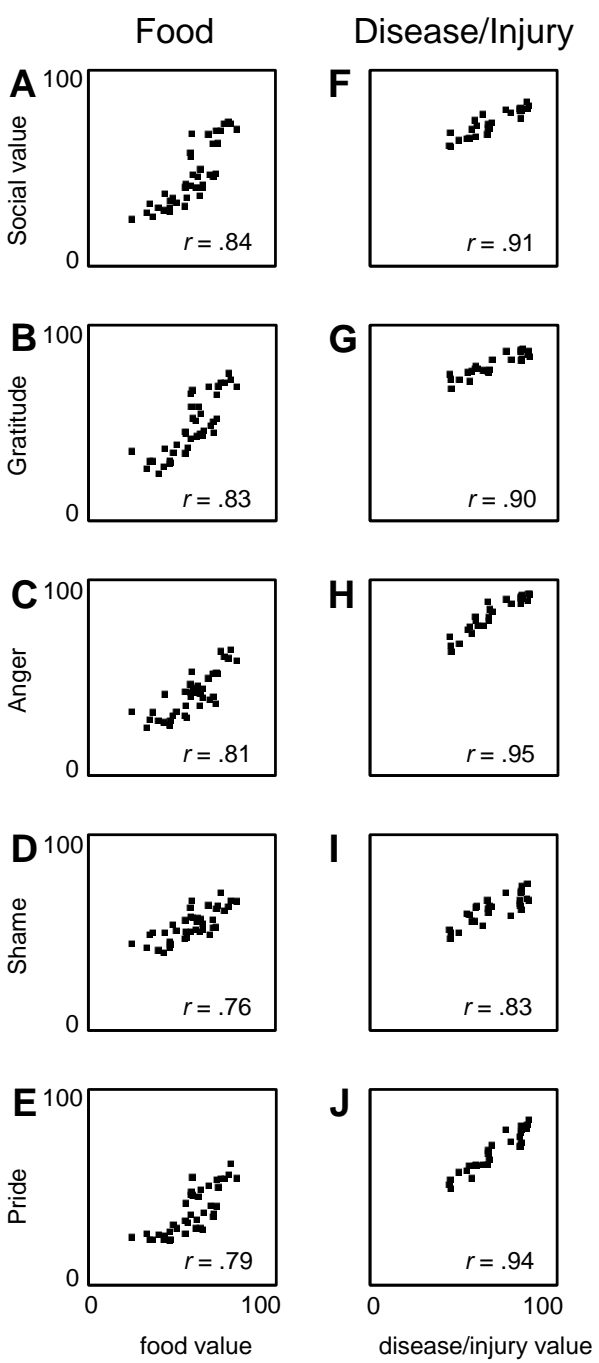

Fig. 1. Scatter plots: Ratings of social value, gratitude, anger, shame, and pride as a function of: the food values imputed to the food items (Study 1; panels A-E), and the (negative)

disease/injury values imputed to the diseases and injuries (Study 2; panels F-J). Note: Each point represents the mean rating of food value (or disease/injury value) and the mean rating of social value (or social emotion) regarding one food item (or one disease/injury). Ratings of food value, disease/injury value, social value, gratitude, anger, shame, and pride were given by different participants. $\mathrm{N}$ on which the correlations are based $=40$ food items; 28 diseases/injuries. 


\section{Study 2. Bads: Diseases and injuries}

\section{Method}

Methods were similar as those used in Study 1, but with respect to diseases and injuries instead of food items. Procedure, stimuli, sample size, exclusion criteria, predictions, and analyses were preregistered before data collection began: https://aspredicted.org/blind.php? $\mathrm{x}=\mathrm{pk} 6 \mathrm{n} 96$.

\section{Participants and procedure}

The total number of participants to be recruited was set at 180: 30 participants per condition. I collected data with Amazon Mechanical Turk from 184 participants (88 females) in the United States. Ten participants were excluded from analyses due to inattention. This resulted in an effective sample of 174 participants (84 females) (age: $\mathrm{M}=39, \mathrm{SD}=13$ ).

The stimuli consist of 28 brief questions relevant to 28 diseases and injuries; one question per disease/injury. The following are some of the items included in the stimuli: a hip fracture; a hand laceration wound; a foot puncture wound; a bruised shoulder; malaria; leprosy. As in Study 1, participants were randomly assigned to one of six between-subjects conditions: disease/injury value, social value, gratitude, anger, shame, pride. In all six conditions participants gave their responses about the same basic set of 28 diseases and injuries. The main difference between the conditions was the specific questions that were asked about the diseases and injuries.

Participants were asked the following questions, for each of the 28 diseases and injuries. In the disease/injury value condition: How bad would it be for them if they had the disease/injury. In the social value condition, how positively the participants would view a target individual if the target were able to cure the disease/injury. In the gratitude condition: How much gratitude the participants would feel toward a target individual if the participant had the disease/injury and the target treated and cured the participant. In the anger condition: How much anger the participants would feel at a target individual if the target caused the participant to get the disease/injury (on purpose). In the shame condition: How much shame the participants would feel if they caused a target individual to get the disease/injury and people found out about that. In the pride condition: How much pride the participants would feel if a target individual had the disease/injury and the participant treated and cured the target.

Participants gave their responses on the following scales. In the disease/injury value condition: 0 (not bad at all) to 100 (extremely bad). In the social value condition: 0 (not positively at all) to 100 (extremely positively). In the gratitude condition: 0 (no gratitude at all) to 100 (extreme gratitude). In the anger condition: 0 (no anger at all) to 100 (extreme anger). In the shame condition: 0 (no shame at all) to 100 (extreme shame). In the pride condition: 0 (no pride at all) to 100 (extreme pride).

Each participant completed one of the six sets of 28 questions. The 28 questions were presented in randomized order within conditions. The questions and the disease/injury items are described in the Appendix, Tables S2 \& S4.

\section{Results}

The stimuli and the data are available in the OSF repository: https://osf.io/7tdkh/?view_only=c25edd59103c41b48e55334cc63f4b7b. The descriptive statistics are provided in Table $\mathrm{S} 4$.

Do participants agree on how they rate the diseases and injuries? Yes. To measure between-participant agreement in their how they rate the 28 diseases and injuries relative to one 
another, I computed intra-class correlations (ICC). There was widespread agreement: disease/injury value: $\operatorname{ICC}(2,31)=.94$; social value: $\operatorname{ICC}(2,27)=.89$; gratitude: $\operatorname{ICC}(2,29)=$ .84 ; anger: $\operatorname{ICC}(2,29)=.92$; shame: $\operatorname{ICC}(2,29)=.81$; pride: $\operatorname{ICC}(2,29)=.90$; all $P \mathrm{~s}<<.05$.

Do the disease/injury values imputed to the diseases and injuries correlate positively with the social values and the social emotions elicited by the diseases and injuries? Yes. The disease/injury values imputed to the diseases and injuries correlated positively with the social values and the social emotions elicited on the basis of the diseases and injuries. For each of the 28 disease/injury items, I calculated the mean ratings (across participants) of each of the six measures: disease/injury value, social value, gratitude, anger, shame, and pride. The disease/injury values imputed to the diseases and injuries correlated positively with: the social value attached to target individuals who are able to cure the disease/injury $\left(r=.91, P=10^{-11}\right)$, the intensity of gratitude directed at targets who cure the disease/injury the participant suffers from $\left(r=.90, P=10^{-10}\right)$, the intensity of anger directed at targets who (on purpose) cause the participant to get the disease/injury $\left(r=.95, P=10^{-13}\right)$, the intensity of shame felt if the participant caused a target to get the disease/injury and people found out $\left(r=.83, P=10^{-7}\right)$, and the intensity of pride felt if the participant cured a target who suffers from the disease/injury $(r=$ $.94, P=10^{-13}$ ) (Figs. 1, panels F-J; and Table 3). Further, these associations held in mixed models predicting ratings of social value (or ratings of social emotions) from ratings of disease/injury value across the 28 disease/injury items. In these mixed models, the intercept and slope of social value ratings (or emotion ratings) were modeled as fixed effects while the participant-level social value (or emotion) intercept was modeled as a random effect (see Table 2 for model statistics).

Do the ratings of social value and social emotions correlate positively with one other? Yes. The ratings of social value, gratitude, anger, shame, and pride were positively correlated with one other, with a mean $r=.84(\mathrm{SD}=.07$; minimum $r=.65$; maximum $r=.90 ; \mathrm{N} r$ values $=10)$; $P$ values $=10^{-10}-10^{-4}$. 
Running head: HUMAN VALUES

\section{Table 3}

Study 2. Correlations between participants' ratings regarding the disease/injury items.

$\begin{array}{lllll}(1) & (2) & \text { (3) } & \text { (4) } & \text { (5) }\end{array}$

(1) Disease/injury value

(2) Social value

.91

(3) Gratitude

$.90 \quad .88$

(4) Anger

$\begin{array}{lll}.95 & .84 & .89\end{array}$

(5) Shame

$\begin{array}{llll}.83 & .65 & .80 & .87\end{array}$

(6) Pride

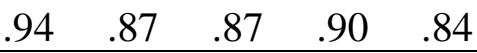

Note: Coefficients are Pearson's $r \mathrm{~s}$. $\mathrm{N}$ on which the correlations are based $=$ number of items $=28$. Ratings of disease/injury value, social value, gratitude, anger, shame, and pride were given by different participants. Directional predictions; all tests 1-tailed; all $P \mathrm{~s}<<.05$. 


\section{Discussion}

Integration is one prerequisite for valuing things aptly. Those internal computations which take value information as input must deliver their outputs with an intensity or magnitude proportional to the value information taken as input. This is so whether the computations output value information or other formats of information - motivation, emotion, judgment, decision, motor control, etc. In this way, the computations that are performed on the basis of value information avoid the dual errors of delivering outputs with insufficient or excessive intensity. Consistent with the integration hypothesis, the social value that valuers impute to a target individual, as well as the intensities of gratitude, anger, shame, and pride felt by valuers, closely track both the (positive) food values that valuers impute to food items (Study 1) and the (negative) disease/injury values that valuers impute to diseases and injuries (Study 2).

Accuracy is another prerequisite for valuing things aptly. The value imputed to a thing must reflect the affordances that the thing has on the valuer (ancestrally, at least). Consistent with the accuracy hypothesis, the food values that valuers impute to food items, as well as the social value imputed to target individuals, and the gratitude, anger, shame, and pride felt by valuers, all track the nutrient content of those food items - in particular their protein content and carbohydrate content (Study 1).

Here, I have focused on social value, motivation, and social emotions. These are some of the cognitive elements that value information shapes. But there are more. Put generally, value information is expected to serve as input to any and all systems whose use of value information would have redounded in net fitness benefits ancestrally. There is evidence that food value information, for instance, is used internally to regulate - in addition to social value and social emotions - appetite (Hinton et al., 2004), visual attention (Motoki et al., 2018; see also Krajbich et al., 2010), spatial memory (New et al., 2007; de Vries et al., 2020), foraging decisions (Hill et al., 1987), sharing decisions (Gurven, 2004; Kaplan et al., 1985; Kaplan et al., 2012), disgust and nausea (Profet, 1992), and food taboos (Fessler et al., 2002; Henrich \& Henrich, 2010; Navarrete $\&$ Fessler, 2003). How and where human value information is computed and routed internallythe human valuome - is yet to be mapped comprehensively.

Task analysis suggests the machinery that enables human value computation is immensely complex. Many more requirements appear necessary beyond integration and accuracy. Above, I noted the need for content-specificity. The cues the architecture exploits to compute value and the ways that cue relates to fitness affordance can vary highly from one evolutionarily-relevant class of thing (or organism or event or state or affairs) to the next. The logic of valuation can vary highly even within narrowly defined classes of things, across affordances-e.g., the kinship value of a target to a valuer has opposite effects on the value of helping the target vs. having sex with the target. Thus, different classes of things call for different, content-specific valuation procedures. A large body of evidence suggests the existence of specialized procedures to compute the value of: food (Krebs, 2009; Billing \& Sherman, 1998; Wertz \& Wynn, 2014); tools (DiYanni \& Kelemen, 2008); landscapes (Falk \& Balling, 2010); actions (Gergely et al., 2002; Liu \& Spelke, 2017); goals (Liu et al., 2017); beliefs (Baumard \& Boyer, 2013; Boyer \& Petersen, 2018; Sperber, 1996); stories (Barnes \& Bloom, 2014; Scalise Sugiyama, 2017; Wiessner, 2014); resource allocations (Almas et al., 2010; DeScioli et al., 2014; Petersen et al., 2012); moral choices (Guzmán et al., under review), social partners (Fiske et al., 2007; Sugiyama, 2005; Eisenbruch et al., 2016; Lim, 2012; Delton \& Robertson, 2016; Sell, Lukazsweski, et al., 2017; Sznycer et al., 2019; Smith et al., 2017b; Krems \& Conroy-Beam, 2020); allies (Benenson, 2013; Watkins \& Jones, 2016); and leaders (Kakkar \& Sivanathan, 
2017; Laustsen \& Petersen, 2017), among others. Many more pre-requisites for value computation are expected besides content-specificity, integration, and accuracy.

Human values can and do vary: throughout history (Elias, 1978; Inglehart, 2008; Morris, 2015; Pinker, 2012), throughout the individual's development (House et al., 2013), across populations, cultures, ecologies, moral communities, and individuals (Gelfand et al., 2011; Hofstede, 2001; Inglehart, 2008; Singer, 2011), and across situations within individuals (Aarøe \& Petersen, 2014; DeScioli et al., 2014). This suggests that values are sometimes computed to match not an objective standard (e.g., the protein content of food) but a local, possibly variable social consensus - the values that fellow group members are inferred to hold (Yu et al., 2021; see also Kuran, 1997; Zentall \& Galef, 1988; Rendell et al., 2010). However, note that socially contingent values appear to reflect variation in how the open parameters of the valuation architecture are filled in from one individual or community or era to the next, rather than variation in the valuation architecture itself. This is suggested by the fact that changes in task specification can lead to rapid, even reversible, individual-level changes in valuation (Aarøe \& Petersen, 2014; Nettle \& Saxe, 2020; Yamagishi et al., 2008) which are commensurate in size with the population-level differences that are often credited to culture. This is suggested also by the fact that population-level values can vary orders of magnitude faster than what it takes for natural selection to build complex adaptations. This is suggested also by the fact that a highly complex psychology of valuation persists in humans despite sexual recombination and interbreeding across human groups (Tooby \& Cosmides, 1990a). Incidentally, it is of note that even socially contingent values can display deep regularities across populations that are mutually remote in space, time, and culture space (Brown, D. E., 1991). For example, there are crosscultural similarities in the actions that are deemed socially disgraceful (Sznycer, Xygalatas, Agey, et al., 2018), in the actions that are deemed virtuous (Curry et al., 2019), in the actions that are believed to lead to high social status (Durkee et al., 2020), in the actions that are considered more or less morally permissible (Awad et al., 2020; Sznycer \& Patrick, 2020), and in the characteristics that are desirable in romantic partners (Buss, 1989).

Further research is needed to know whether the present findings replicate with non-selfreported measures of value and emotion. Further research is needed to establish whether accuracy and integration obtain in the valuation of goods and bads other than those evaluated here, and in other populations and cultures. More generally, further research is needed to map the psychology of valuation, including its invariant principles and its open parameters.

Diverse research perspectives have been brought to bear on human values. One of them (e.g., Plato, 1943; Maslow, 2013; Rokeach, 1973; Schwartz \& Bilsky, 1987), descriptive and typological, has described values held by humans across cultures. Another, neuroscientific perspective focuses on the neural basis of value computation (e.g., Levy \& Glimcher, 2012; Lin et al., 2012; Crockett et al., 2017; McNamee et al., 2013). A third perspective, of functional and content-specific orientation, maps the symbols and rules that enable value computation within each of various narrow domains: animals, plants, tools, actions, landscapes, kin, mates, and so on (e.g., Falk \& Balling, 2010; Gergely et al., 2002; Krebs, 2009; Lim, 2012; Eisenbruch et al., 2016; Laustsen \& Petersen, 2017).

A cognitive perspective draws from, and complements, these various perspectives. The descriptive perspective characterizes abstract values held by humans worldwide, or within broad cultural regions (e.g., security, survival, benevolence). As noted above, however, humans also value a vast number of specific things. Further, whereas some things are valued by all or by many (the focus of the descriptive perspective), other things are valued by some, by all during 
specific periods in development, differentially or exclusively by members of one sex, etc. A cognitive perspective is well-suited to elaborate on how, when, and why people value the things that they value.

A cognitive perspective can complement the neuroscience of valuation. If value is spawned by information-processing procedures as a matter of function, then questions about value computation might be raised and answered more straightforwardly (and cheaply) from a cognitive perspective. Cognition offers a natural perspective from which to, for instance, generate hypotheses about requisite features for human value computation (e.g., integration, accuracy) — whether said values are computed in the brain, elsewhere in the nervous system (see Harel et al., 2008), or within cells (Holm \& Vikström, 2014; see also Gallistel, 2017).

Finally, a cognitive perspective can complement the content-specificity perspective. Both perspectives assume that functional specialization and content-specificity are necessary for value computation. But the former perspective suggests, in addition, that human value computation recruits a host of content-general procedures, albeit functionally specialized for value computation (e.g., procedures for value integration) (see Jackendoff, 2006; Levy \& Glimcher, 2012).

Values are not the sole province of ethicists, traditionalists, and busybodies. Values are essential computational elements that enable the life-supporting operations of humans and other organisms. A cognitive perspective is a promising avenue to elucidate the nature of human values.

\section{Acknowledgments}

Tomás Lopez Seal provided helpful comments.

\section{References}

Aarøe, L., \& Petersen, M. B. (2014). Crowding out culture: Scandinavians and Americans agree on social welfare in the face of deservingness cues. The Journal of Politics, 76(3), 684697.

Aktipis, A., Cronk, L., Alcock, J., Ayers, J. D., Baciu, C., Balliet, D., Boddy, A. M., Curry, O. S., Krems, J. A., \& Muñoz, A. (2018). Understanding cooperation through fitness interdependence. Nature Human Behaviour, 2(7), 429-431.

Algoe, S. B., Haidt, J., \& Gable, S. L. (2008). Beyond Reciprocity: Gratitude and Relationships in Everyday Life. Emotion, 8, 425-429.

Almas, I., Cappelen, A. W., Sørensen, E. Ø., \& Tungodden, B. (2010). Fairness and the development of inequality acceptance. Science, 328(5982), 1176-1178.

Al-Shawaf, L., Conroy-Beam, D., Asao, K., \& Buss, D. M. (2016). Human emotions: An evolutionary psychological perspective. Emotion Review, 8(2), 173-186.

Ames, B. N., Profet, M., \& Gold, L. S. (1990). Dietary pesticides (99.99\% all natural). Proceedings of the National Academy of Sciences, 87(19), 7777-7781.

Awad, E., Dsouza, S., Shariff, A., Rahwan, I., \& Bonnefon, J.-F. (2020). Universals and variations in moral decisions made in 42 countries by 70,000 participants. Proceedings of the National Academy of Sciences, 117(5), 2332-2337.

Barnes, J. L., \& Bloom, P. (2014). Children's preference for social stories. Developmental Psychology, 50(2), 498-503.

Barrett, H. C. (2005). Enzymatic computation and cognitive modularity. Mind \& Language, 20(3), 259-287. 
Barth, H., La Mont, K., Lipton, J., Dehaene, S., Kanwisher, N., \& Spelke, E. (2006). Nonsymbolic arithmetic in adults and young children. Cognition, 98(3), 199-222.

Basten, U., Biele, G., Heekeren, H. R., \& Fiebach, C. J. (2010). How the brain integrates costs and benefits during decision making. Proceedings of the National Academy of Sciences, 107(50), 21767-21772.

Baumard, N., \& Boyer, P. (2013). Religious beliefs as reflective elaborations on intuitions: A modified dual-process model. Current Directions in Psychological Science, 22(4), 295300.

Benenson, J. F. (2013). The development of human female competition: Allies and adversaries. Philosophical Transactions of the Royal Society B: Biological Sciences, 368(1631), 20130079.

Billing, J., \& Sherman, P. W. (1998). Antimicrobial functions of spices: Why some like it hot. The Quarterly Review of Biology, 73(1), 3-49.

Boyer, P., \& Petersen, M. B. (2018). Folk-economic beliefs: An evolutionary cognitive model. Behavioral and Brain Sciences, 41.

Brown, D. E. (1991). Human universals. McGraw-Hill.

Buss, D. M. (1989). Sex differences in human mate preferences: Evolutionary hypotheses tested in 37 cultures. Behavioral and Brain Sciences, 12(1), 1-14.

Charnov, E. L. (1976). Optimal foraging, the marginal value theorem. Theoretical Population Biology, 9, 129-136.

Cohen, A. S., Chun, R., \& Sznycer, D. (2020). Do pride and shame track the evaluative psychology of audiences? Preregistered replications of Sznycer et al. (2016, 2017). Royal Society Open Science, 7(5), 191922.

Conroy-Beam, D., \& Buss, D. M. (2017). Euclidean distances discriminatively predict short-term and long-term attraction to potential mates. Evolution and Human Behavior, 38(4), 442450.

Cosmides, L., \& Tooby, J. (1992). Cognitive adaptations for social exchange. In The adapted mind: Evolutionary psychology and the generation of culture (J. H. Barkow, L. Cosmides, J. Tooby, Eds) (pp. 163-228). Oxford University Press.

Cosmides, L., \& Tooby, J. (1994). Mapping the mind: Domain specificity in cognition and culture (Eds: L. A. Hirschfeld \& S. A. Gelman). In Origins of domain specificity: The evolution of functional organization (pp. 85-116). Cambridge University Press.

Cosmides, L., \& Tooby, J. (2000). Evolutionary psychology and the emotions. In Handbook of Emotions, 2nd Edition (M. Lewis \& J. M. Haviland-Jones, Eds.) (pp. 91-115). Guilford.

Crockett, M. J., Siegel, J. Z., Kurth-Nelson, Z., Dayan, P., \& Dolan, R. J. (2017). Moral transgressions corrupt neural representations of value. Nature Neuroscience, 20(6), 879885.

Croxson, P. L., Walton, M. E., O’Reilly, J. X., Behrens, T. E., \& Rushworth, M. F. (2009). Effort-based cost-benefit valuation and the human brain. Journal of Neuroscience, 29(14), 4531-4541.

Curry, O. S., Mullins, D. A., \& Whitehouse, H. (2019). Is it good to cooperate? Testing the theory of Morality-as-Cooperation in 60 Societies. Current Anthropology, 60(1), 47-69.

Daly, M., \& Wilson, M. (1988). Homicide. Aldine de Gruyter.

de Vries, R., Morquecho-Campos, P., de Vet, E., de Rijk, M., Postma, E., de Graaf, K., Engel, B., \& Boesveldt, S. (2020). Human spatial memory implicitly prioritizes high-calorie foods. Scientific Reports, 10(1), 15174. 
Dehaene, S. (2009). Origins of mathematical intuitions: The case of arithmetic. Annals of the New York Academy of Sciences, 1156(1), 232-259.

Delton, A. W., \& Robertson, T. E. (2016). How the mind makes welfare tradeoffs: Evolution, computation, and emotion. Current Opinion in Psychology, 7, 12-16.

DeScioli, P., Massenkoff, M., Shaw, A., Petersen, M. B., \& Kurzban, R. (2014). Equity or equality? Moral judgments follow the money. Proceedings of the Royal Society B: Biological Sciences, 281(1797), 20142112.

DiYanni, C., \& Kelemen, D. (2008). Using a bad tool with good intention: Young children's imitation of adults' questionable choices. Journal of Experimental Child Psychology, 101(4), 241-261.

Durkee, P. K., Lukaszewski, A. W., \& Buss, D. M. (2019). Pride and shame: Key components of a culturally universal status management system. Evolution and Human Behavior, 40(5), 470-478.

Durkee, P. K., Lukaszewski, A. W., \& Buss, D. M. (2020). Psychological foundations of human status allocation. Proceedings of the National Academy of Sciences, 117(35), 2123521241.

Eisenbruch, A. B., Grillot, R. L., Maestripieri, D., \& Roney, J. R. (2016). Evidence of partner choice heuristics in a one-shot bargaining game. Evolution and Human Behavior, 37(6), 429-439.

Elias, N. (1978). The Civilizing Process: The history of manners.

Elliot, A. J. (2006). The hierarchical model of approach-avoidance motivation. Motivation and Emotion, 30(2), 111-116.

Falk, J. H., \& Balling, J. D. (2010). Evolutionary influence on human landscape preference. Environment and Behavior, 42(4), 479-493.

Felson, R. B. (1982). Impression management and the escalation of aggression and violence. Social Psychology Quarterly, 245-254.

Fessler, D. M. (1999). Toward an understanding of the universality of second order emotions. Beyond Nature or Nurture: Biocultural Approaches to the Emotions, 75-116.

Fessler, D. T., Bayley, T., Dye, L., Brown, J., Flaxman, S., Leeners, B., Nappi, R., OConnor, K., Sellen, D., \& Sherman, P. (2002). Reproductive immunosuppression and diet: An evolutionary perspective on pregnancy sickness and meat consumption. Current Anthropology, 43(1), 19-61.

Fiske, S. T., Cuddy, A. J., \& Glick, P. (2007). Universal dimensions of social cognition: Warmth and competence. Trends in Cognitive Sciences, 11(2), 77-83.

Forster, D. E., Pedersen, E. J., Smith, A., McCullough, M. E., \& Lieberman, D. (2017). Benefit valuation predicts gratitude. Evolution and Human Behavior, 38(1), 18-26.

Galati, D., Sini, B., Schmidt, S., \& Tinti, C. (2003). Spontaneous facial expressions in congenitally blind and sighted children aged 8-11. Journal of Visual Impairment and Blindness, 97(7), 418-428.

Gallistel, C. R. (1990). The organization of learning. The MIT Press.

Gallistel, C. R. (2017). The coding question. Trends in Cognitive Sciences, 21(7), 498-508.

Gallistel, C. R., \& Gelman, R. (1992). Preverbal and verbal counting and computation. Cognition, 44(1-2), 43-74.

Gelfand, M. J., Raver, J. L., Nishii, L., Leslie, L. M., Lun, J., Lim, B. C., Duan, L., Almaliach, A., Ang, S., \& Arnadottir, J. (2011). Differences between tight and loose cultures: A 33nation study. Science, 332(6033), 1100-1104. 
Gergely, G., Bekkering, H., \& Király, I. (2002). Rational imitation in preverbal infants. Nature, 415(6873), 755-755.

Gilbert, P. (1997). The evolution of social attractiveness and its role in shame, humiliation, guilt and therapy. British Journal of Medical Psychology, 70(2), 113-147.

Gilbert, P. (1998). What is shame? Some core issues and controversies. In Shame: Interpersonal behavior, psychopathology, and culture (P. Gilbert \& B. Andrews, Eds.) (pp. 3-38).

Green, L., Myerson, J., \& Vanderveldt, A. (2014). Delay and probability discounting. In The Wiley Blackwell handbook of operant and classical conditioning (Eds: F. K. McSweeney \& E. S. Murphy) (pp. 307-337). Wiley-Blackwell.

Gurven, M. (2004). Reciprocal altruism and food sharing decisions among Hiwi and Ache hunter-gatherers. Behavioral Ecology and Sociobiology, 56(4), 366-380.

Guzmán, R. A., Barbato, M. T., Sznycer, D., \& Cosmides, L. (under review). A moral tradeoff system produces intuitive moral judgments that are rational, context-dependent, and strike a balance between conflicting moral duties.

Harel, R., Asher, I., Cohen, O., Israel, Z., Shalit, U., Yanai, Y., Zinger, N., \& Prut, Y. (2008). Computation in spinal circuitry: Lessons from behaving primates. Behavioural Brain Research, 194(2), 119-128.

Henrich, J., \& Henrich, N. (2010). The evolution of cultural adaptations: Fijian food taboos protect against dangerous marine toxins. Proceedings of the Royal Society B: Biological Sciences, 277(1701), 3715-3724.

Hill, K., Kaplan, H., Hawkes, K., \& Hurtado, A. M. (1987). Foraging decisions among Ache hunter-gatherers: New data and implications for optimal foraging models. Ethology and Sociobiology, 8(1), 1-36.

Hinton, E. C., Parkinson, J. A., Holland, A. J., Arana, F. S., C. Roberts, A., \& Owen, A. M. (2004). Neural contributions to the motivational control of appetite in humans. European Journal of Neuroscience, 20(5), 1411-1418.

Hofmann, W., De Houwer, J., Perugini, M., Baeyens, F., \& Crombez, G. (2010). Evaluative conditioning in humans: A meta-analysis. Psychological Bulletin, 136(3), 390-421.

Hofstede, G. (2001). Culture's consequences: Comparing values, behaviors, institutions and organizations across nations (2nd ed.). Sage.

Holm, A., \& Vikström, E. (2014). Quorum sensing communication between bacteria and human cells: Signals, targets, and functions. Frontiers in Plant Science, 5, 309.

House, B. R., Silk, J. B., Henrich, J., Barrett, H. C., Scelza, B. A., Boyette, A. H., Hewlett, B. S., McElreath, R., \& Laurence, S. (2013). Ontogeny of prosocial behavior across diverse societies. Proceedings of the National Academy of Sciences, 110(36), 14586-14591.

Inglehart, R. (2007). Postmaterialist values and the shift from survival to self-expression values. In The Oxford Handbook of Political Behavior (Eds: R. Dalton \& H. D. Klingemann) (pp. 223-239). Oxford University Press.

Inglehart, R. F. (2008). Changing values among western publics from 1970 to 2006. West European Politics, 31(1-2), 130-146.

Jackendoff, R. (2006). The peculiar logic of value. Journal of Cognition and Culture, 6(3-4), 375-407.

Judd, C. M., Westfall, J., \& Kenny, D. A. (2012). Treating stimuli as a random factor in social psychology: A new and comprehensive solution to a pervasive but largely ignored problem. Journal of Personality and Social Psychology, 103(1), 54. 
Kakkar, H., \& Sivanathan, N. (2017). When the appeal of a dominant leader is greater than a prestige leader. Proceedings of the National Academy of Sciences, 114(26), 6734-6739.

Kaplan, H., Hill, K., Cadelina, R. V., Hayden, B., Hyndman, D. C., Preston, R. J., Smith, E. A., Stuart, D. E., \& Yesner, D. R. (1985). Food sharing among ache foragers: Tests of explanatory hypotheses [and comments and reply]. Current Anthropology, 26(2), 223246.

Kaplan, H. S., Schniter, E., Smith, V. L., \& Wilson, B. J. (2012). Risk and the evolution of human exchange. Proceedings of the Royal Society B: Biological Sciences, 279(1740), 2930-2935.

Krajbich, I., Armel, C., \& Rangel, A. (2010). Visual fixations and the computation and comparison of value in simple choice. Nature Neuroscience, 13, 1292-1298.

Krebs, J. R. (2009). The gourmet ape: Evolution and human food preferences. The American Journal of Clinical Nutrition, 90(3), 707S-711S.

Krems, J. A., \& Conroy-Beam, D. (2020). First tests of Euclidean preference integration in friendship: Euclidean friend value and power of choice on the friend market. Evolution and Human Behavior, 41, 188-198.

Kuran, T. (1997). Private truths, public lies. Harvard University Press.

Landers, M, Sznycer, D., \& Al-Shawaf, L. (In press). Shame. In The Oxford Handbook of Evolution and the Emotions (Eds: L. Al-Shawaf \& T. K. Shackelford). Oxford University Press.

Laustsen, L., \& Petersen, M. B. (2017). Perceived conflict and leader dominance: Individual and contextual factors behind preferences for dominant leaders. Political Psychology, 38(6), 1083-1101.

Levy, D. J., \& Glimcher, P. W. (2011). Comparing apples and oranges: Using reward-specific and reward-general subjective value representation in the brain. Journal of Neuroscience, 31(41), 14693-14707.

Levy, D. J., \& Glimcher, P. W. (2012). The root of all value: A neural common currency for choice. Current Opinion in Neurobiology, 22(6), 1027-1038.

Lewin, K. (1935). A dynamic theory of personality-selected papers. McGraw-Hill.

Lieberman, D., Tooby, J., \& Cosmides, L. (2007). The architecture of human kin detection. Nature, 445, 727-731.

Lim, J. (2012). Welfare tradeoff ratios and emotions: Psychological foundations of human reciprocity. University of California, Santa Barbara.

Lin, A., Adolphs, R., \& Rangel, A. (2012). Social and monetary reward learning engage overlapping neural substrates. Social Cognitive and Affective Neuroscience, 7(3), 274281.

Liu, S., \& Spelke, E. S. (2017). Six-month-old infants expect agents to minimize the cost of their actions. Cognition, 160, 35-42.

Liu, S., Ullman, T. D., Tenenbaum, J. B., \& Spelke, E. S. (2017). Ten-month-old infants infer the value of goals from the costs of actions. Science, 358(6366), 1038-1041.

Maslow, A. H. (2013). Toward a psychology of being. Simon and Schuster.

McNamee, D., Rangel, A., \& O’doherty, J. P. (2013). Category-dependent and categoryindependent goal-value codes in human ventromedial prefrontal cortex. Nature Neuroscience, 16(4), 479-485.

Morris, I. (2015). Foragers, farmers, and fossil fuels. Princeton University Press. 
Motoki, K., Saito, T., Nouchi, R., Kawashima, R., \& Sugiura, M. (2018). Tastiness but not healthfulness captures automatic visual attention: Preliminary evidence from an eyetracking study. Food Quality and Preference, 64, 148-153.

Navarrete, C. D., \& Fessler, D. (2003). Meat is good to taboo: Dietary proscriptions as a product of the interaction of psychological mechanisms and social processes. Journal of Cognition and Culture, 3(1), 1-40.

Nettle, D., \& Saxe, R. (2020). Preferences for redistribution are sensitive to perceived luck, social homogeneity, war and scarcity. Cognition, 198, 104234.

New, J., Krasnow, M. M., Truxaw, D., \& Gaulin, S. J. (2007). Spatial adaptations for plant foraging: Women excel and calories count. Proceedings of the Royal Society B: Biological Sciences, 274(1626), 2679-2684.

Oprea, R., Henwood, K., \& Friedman, D. (2011). Separating the Hawks from the Doves: Evidence from continuous time laboratory games. Journal of Economic Theory, 146(6), 2206-2225.

Park, S. Q., Kahnt, T., Rieskamp, J., \& Heekeren, H. R. (2011). Neurobiology of value integration: When value impacts valuation. Journal of Neuroscience, 31(25), 9307-9314.

Petersen, M. B., Sznycer, D., Cosmides, L., \& Tooby, J. (2012). Who deserves help? Evolutionary psychology, social emotions, and public opinion about welfare. Political Psychology, 33(3), 395-418.

Piddocke, S. (1965). The potlatch system of the Southern Kwakiutl: A new perspective. Southwestern Journal of Anthropology, 21(3), 244-264.

Pinker, S. (2012). The better angels of our nature: Why violence has declined. Penguin. Plato. (1943). Plato's The Republic. Books, Inc.

Profet, M. (1992). Pregnancy sickness as adaptation: A deterrent to maternal ingestion of teratogens. In The adapted mind: Evolutionary psychology and the generation of culture (J. H. Barkow, L. Cosmides, J. Tooby, Eds) (pp. 327-365). Oxford University Press.

Rangel, A. (2009). The computation and comparison of value in goal-directed choice. In Neuroeconomics (pp. 425-440). Elsevier.

Rendell, L., Boyd, R., Cownden, D., Enquist, M., Eriksson, K., Feldman, M. W., Fogarty, L., Ghirlanda, S., Lillicrap, T., \& Laland, K. N. (2010). Why copy others? Insights from the social learning strategies tournament. Science, 328(5975), 208-213.

Roesch, M. R., \& Olson, C. R. (2004). Neuronal activity related to reward value and motivation in primate frontal cortex. Science, 304(5668), 307-310.

Rokeach, M. (1973). The nature of human values. Free press.

Scalise Sugiyama, M. (2017). Oral storytelling as evidence of pedagogy in forager societies. Frontiers in Psychology, 8, 471.

Schrock, J. M., Snodgrass, J. J., \& Sugiyama, L. S. (2019). Lassitude: The emotion of being sick. Evolution and Human Behavior, 41(1), 44-57.

Schwartz, S. H., \& Bilsky, W. (1987). Toward a universal psychological structure of human values. Journal of Personality and Social Psychology, 53(3), 550-562.

Sell, A. (2005). Regulating welfare tradeoff ratios: Three tests of an evolutionary-computational model of human anger. University of California, Santa Barbara (PhD dissertation).

Sell, A. (2011). The recalibrational theory and violent anger. Aggression and Violent Behavior, 16(5), 381-389.

Sell, A., Cosmides, L., \& Tooby, J. (2014). The human anger face evolved to enhance cues of strength. Evolution and Human Behavior, 35(5), 425-429. 
Sell, A., \& Lopez, A. C. (2020). Emotional underpinnings of war: An evolutionary analysis of anger and hatred. In The Handbook of Collective Violence (C. A. Ireland, M. Lewis, A. C. Lopez, \& J. L Ireland, Eds.) (pp. 31-46). Routledge.

Sell, A., Lukazsweski, A. W., \& Townsley, M. (2017). Cues of upper body strength account for most of the variance in men's bodily attractiveness. Proceedings of the Royal Society B: Biological Sciences, 284(1869), 20171819.

Sell, A., \& Sznycer, D. (In press). The recalibrational theory: Anger as a bargaining emotion. In The Oxford Handbook of Evolution and the Emotions (Eds: L. Al-Shawaf \& T. K. Shackelford). Oxford University Press.

Sell, A., Sznycer, D., Al-Shawaf, L., Lim, J., Krauss, A., Feldman, A., Rascanu, R., Sugiyama, L., Cosmides, L., \& Tooby, J. (2017). The grammar of anger: Mapping the computational architecture of a recalibrational emotion. Cognition, 168, 110-128.

Sell, A., Tooby, J., \& Cosmides, L. (2009). Formidability and the logic of human anger. Proceedings of the National Academy of Sciences of the United States of America, 106, 15073-15078.

Shadmehr, R., \& Ahmed, A. A. (2020). Vigor: Neuroeconomics of movement control. MIT Press.

Siegel, E. H., Sands, M. K., Van den Noortgate, W., Condon, P., Chang, Y., Dy, J., Quigley, K. S., \& Barrett, L. F. (2018). Emotion fingerprints or emotion populations? A meta-analytic investigation of autonomic features of emotion categories. Psychological Bulletin, 144(4), 343-393.

Simon, H. A. (1955). A behavioral model of rational choice. The Quarterly Journal of Economics, 69(1), 99-118.

Singer, P. (2011). Changing values for a just and sustainable world. The Governance of Climate Change, 144-161.

Smith, A., Pedersen, E. J., Forster, D. E., McCullough, M. E., \& Lieberman, D. (2017a). Cooperation: The roles of interpersonal value and gratitude. Evolution and Human Behavior, 38(6), 695-703.

Smith, A., Pedersen, E. J., Forster, D. E., McCullough, M. E., \& Lieberman, D. (2017b). Cooperation: The roles of interpersonal value and gratitude. Evolution and Human Behavior, 38(6), 695-703.

Sperber, D. (1996). Explaining culture: A naturalistic approach. Cambridge, MA: Cambridge. Stellar, J. R., \& Stellar, E. (1985). The neurobiology of motivation and reward. Springer.

Sugiyama, L. S. (2005). Physical attractiveness: An adaptationist perspective. In The handbook of evolutionary psychology (Ed: D. M. Buss) (pp. 292-343). Wiley.

Sznycer, D. (2019). Forms and functions of the self-conscious emotions. Trends in Cognitive Sciences, 23(2), 143-157.

Sznycer, D., Al-Shawaf, L., Bereby-Meyer, Y., Curry, O. S., De Smet, D., Ermer, E., Kim, S., Kim, S., Li, N. P., \& Seal, M. F. L. (2017). Cross-cultural regularities in the cognitive architecture of pride. Proceedings of the National Academy of Sciences, 114(8), 18741879.

Sznycer, D. \& Cohen, A. S. (2021a). Are emotions natural kinds after all? Rethinking the issue of response coherence. Evolutionary Psychology. https://doi.org/10.1177/14747049211016009

Sznycer, D. \& Cohen, A. S. (2021b). How pride works. Evolutionary Human Sciences, 3, e10. 
Sznycer, D., Cosmides, L., \& Tooby, J. (2017). Adaptationism carves emotions at their functional joints. Psychological Inquiry, 28(1), 56-62.

Sznycer, D., De Smet, D., Billingsley, J., \& Lieberman, D. (2016). Coresidence duration and cues of maternal investment regulate sibling altruism across cultures. Journal of Personality and Social Psychology, 111(2), 159-177.

Sznycer, D., Delton, A. W., Robertson, T. E., Cosmides, L., \& Tooby, J. (2019). The ecological rationality of helping others: Potential helpers integrate cues of recipients' need and willingness to sacrifice. Evolution and Human Behavior, 40(1), 34-45.

Sznycer, D., \& Lukaszewski, A. W. (2019). The emotion-valuation constellation: Multiple emotions are governed by a common grammar of social valuation. Evolution and Human Behavior, 40(4), 395-404.

Sznycer, D., \& Patrick, C. (2020). The origins of criminal law. Nature Human Behaviour, 4(5), 506-516.

Sznycer, D., Sell, A., \& Dumont, A. (under review). How anger works.

Sznycer, D., Sell, A, \& Lieberman, D. (2021). Forms and functions of the social emotions. Current Directions in Psychological Science, 30(4), 292-299.

Sznycer, D., Tooby, J., Cosmides, L., Porat, R., Shalvi, S., \& Halperin, E. (2016). Shame closely tracks the threat of devaluation by others, even across cultures. Proceedings of the National Academy of Sciences, 113(10), 2625-2630.

Sznycer, D., Xygalatas, D., Agey, E., Alami, S., An, X.-F., Ananyeva, K. I., Atkinson, Q. D., Broitman, B. R., Conte, T. J., \& Flores, C. (2018). Cross-cultural invariances in the architecture of shame. Proceedings of the National Academy of Sciences, 115(39), 97029707.

Sznycer, D., Xygalatas, D., Alami, S., An, X.-F., Ananyeva, K. I., Fukushima, S., Hitokoto, H., Kharitonov, A. N., Koster, J. M., \& Onyishi, C. N. (2018). Invariances in the architecture of pride across small-scale societies. Proceedings of the National Academy of Sciences, $115(33), 8322-8327$.

Tanskanen, A. O., Danielsbacka, M., \& Rotkirch, A. (2021). Kin detection cues and sibling relationship quality in adulthood: The role of childhood co-residence duration and maternal perinatal association. Evolution and Human Behavior. https://doi.org/10.1016/j.evolhumbehav.2021.05.004

Tesser, A., Gatewood, R., \& Driver, M. (1968). Some determinants of gratitude. Journal of Personality and Social Psychology, 9(3), 233-236.

Tooby, J., \& Cosmides, L. (1990a). On the universality of human nature and the uniqueness of the individual: The role of genetics and adaptation. Journal of Personality, 58(1), 17-67.

Tooby, J., \& Cosmides, L. (1990b). The past explains the present: Emotional adaptations and the structure of ancestral environments. Ethology and Sociobiology, 11(4-5), 375-424.

Tooby, J., \& Cosmides, L. (2000). Consider the Source: The Evolution of Adaptations for Decoupling and Metarepresentations. Metarepresentations: A Multidisciplinary Perspective, New York, 53-116.

Tooby, J., \& Cosmides, L. (2008). The evolutionary psychology of the emotions and their relationship to internal regulatory variables. In Handbook of Emotions, 3rd Ed (M. Lewis, J. M. Haviland-Jones \& L. F. Barrett, Eds.) (pp. 114-137). Guilford.

Tooby, J., \& Cosmides, L. (1996). Friendship and the banker's paradox: Other pathways to the evolution of adaptations for altruism. Proceedings-British Academy, 88, 119-144. 
Tooby, J., Cosmides, L., Sell, A., Lieberman, D., \& Sznycer, D. (2008). Internal regulatory variables and the design of human motivation: A computational and evolutionary approach. In Handbook of approach and avoidance motivation (Andrew J. Elliot (Ed.), pp. 251-271). Lawrence Erlbaum Associates.

Tracy, J. L., Shariff, A. F., \& Cheng, J. T. (2010). A naturalist's view of pride. Emotion Review, 2(2), 163-177.

Triandis, H. C. (1993). Collectivism and individualism as cultural syndromes. Cross-Cultural Research, 27(3-4), 155-180.

U.S. Department of Agriculture, Agricultural Research Service. (2019). FoodData Central. fdc.nal.usda.gov

Veblen, T. (1899). Theory of the Leisure Class: An Economic Study in the Evolution of Institutions. Macmillan.

Von Rueden, C. (2014). The roots and fruits of social status in small-scale human societies. In The psychology of social status (Eds. J Cheng, J Tracy, C Anderson) (pp. 179-200). Springer.

Watkins, C. D., \& Jones, B. C. (2016). Competition-related factors directly influence preferences for facial cues of dominance in allies. Behavioral Ecology and Sociobiology, 70(12), 2071-2079.

Weisfeld, G. E., \& Dillon, L. M. (2012). Applying the dominance hierarchy model to pride and shame, and related behaviors. Journal of Evolutionary Psychology, 10(1), 15-41.

Wertz, A. E., \& Wynn, K. (2014). Selective social learning of plant edibility in 6-and 18-monthold infants. Psychological Science, 25(4), 874-882.

Wiessner, P. W. (2014). Embers of society: Firelight talk among the Ju/'hoansi Bushmen. Proceedings of the National Academy of Sciences, 111(39), 14027-14035.

Wyckoff, J. P. (2016). Aggression and emotion: Anger, not general negative affect, predicts desire to aggress. Personality and Individual Differences, 101, 220-226.

$\mathrm{Xu}, \mathrm{F}$. (2003). Numerosity discrimination in infants: Evidence for two systems of representations. Cognition, 89(1), B15-B25.

Yamagishi, T., Hashimoto, H., \& Schug, J. (2008). Preferences versus strategies as explanations for culture-specific behavior. Psychological Science, 19(6), 579-584.

Yu, H., Siegel, J. Z., Clithero, J. A., \& Crockett, M. J. (2021). How peer influence shapes value computation in moral decision-making. Cognition, 211, 104641.

Zentall, T. R., \& Galef, B. G. (1988). Social learning: Psychological and biological perspectives. Psychology Press. 